\title{
Virtus and Causae Primordiales in Berthold's Expositio
}

\author{
Ezequiel Ludueña \\ University of Buenos Aires
}

In the beginning of his Expositio, Berthold presents his interpretation of Proclus's metaphysical universe. The supreme Principle of reality is Unity, which according to Proclus is the same as Goodness. Unity is not a mere concept obtained by way of abstraction, but exists in natura rerum. ${ }^{1}$ This Unity, says Berthold, is an unum quod non est in multis sive multitudine. It is pure act, and creates a second unity, which is an unum quod est in multitudine. It also creates a third unum which participates in the first through the second unum. This third unum is, then, ab alio sive per aliud.

The first unity (unum secundum causam), in a strict sense, is not unity but excess of unity. It is not an unum among others, it is unum ante omne unum et multitudinem; it is an unum non plurificabile, and omnium productivum. ${ }^{2}$

The second unity (unum secundum essentiam) is, for Berthold, a "one-many" because he discerns in it a series of causes which he identifies with Proclus' henads or gods. Following Moerbeke's translations, Berthold calls them unitates or bonitates. This unum is, then, simplex, but not simpliciter simplex. ${ }^{3}$

1 Berthold of Moosburg, Expositio, 1A, p. 74, l. 108.

2 Berthold of Moosburg, Expositio, 1D, p. 77, l. 228-234; and 2E, p. 88, l. 241-244.

3 Berthold of Moosburg, Expositio, 59B, p. 165, l. 65-74: Simplex primi (...) modi est simpliciter et absolute simplex, cuius simplicitas est omnimoda, in qua nulla est plica diversitatis secundum esse aliquo modo. Et hoc non convenit nisi prime bono, quod nulla plica habitudinis ad aliquid intra vel extra dependet secundum esse diversum a se ipso. Et hoc est simplex omnino et omnimode in fine simplicitatis, cuius simplicitas nulli causato convenire potest. Est et alia simplicitas, quae non habet plicam habitudinis secundum esse ad compositiones intra, cum non constet ex diversis intentionibus, licet habeat dependentiam ad causam extra, a qua accipit id, quod est. Et hoc non est omnino simplex, sed contractum ad determinatum modum et ex hoc conclusum intra ordinem partialem, scilicet unialem, et intra totalem ordinem universi. The underlined sections come from Albert the Great's Summa theologiae I, III, 21.

(C) KONINKLIJKE BRILL NV, LEIDEN, THE NETHERLANDS, 2022 ～DOI:10.1163/9789004501331_010

This is an open access chapter distributed under the terms of the CC BY-NC 4.o licensę 
Whereas the first is an unum simpliciter, the unum secundum essentiam is a quoddam unum. It is contracted or limited unity. ${ }^{4}$ But it differs from the third kind of unity (unum secundum participationem) in that, even if contracted, its essence is unity, whereas unum secundum participationem results from a composition.

The absolute One pre-contains every possible kind of unity. ${ }^{5}$ Every unity presupposes it, but the One does not have its unity from another, but from itself. It is prime unum. ${ }^{6}$ And because not only every kind of unity but everything presupposes the prime unum, it creates everything. The One, and only the One, creates.

In terms of similarity of nature, the first product of the unum secundum causam is the unum secundum essentiam. This unum is, as we said, the realm of the unitates or bonitates. Each one of them is, thus, an unum or bonum per essentiam. Whereas the One is unum strictly secundum causam, each henad has, properly speaking, an essence, and every essence is contracted. Because they possess the essence of unity in this contracted way, Berthold contends that they are not prime unum, but primo unum. That is to say, the One is the source of oneness and the henads are, formaliter, the first unity.

Nevertheless, if, in regard to its essence, the gods or unitates are pure unity, in respect to multiplicity, they are principles of determination. ${ }^{7}$ They constitute a plurality of causes, immediata ad ipsum prime unum. ${ }^{8}$ Berthold distinguishes six henads, i.e. six principles of determination: prime virtus (or infinitas), prime entitas, prime vita, prime intellectualitas, prime animealitas and prime naturalitas. ${ }^{9}$ The use of the adverb prime indicates that the unitates, in regard to

4 Berthold of Moosburg, Expositio, 2E, p. 88, 1. 245-247: Unum autem secundum essentiam est quoddam unum eo, quod deficit a superplenitudine simpliciter unius: tum quia est contractum, illud vero illimitatum, tum quia licet sit simplex, tamen non est simpliciter simplex (...).

5 Berthold of Moosburg, Expositio, 65D, p. 203, 1. 82-84: (...) et sic praehabet omnia, in quibus ipsa eadem intentio contracta est vel contrahibilis, nobiliori, quia absolutiori modo, quam sint in se ipsis, et sic etiam dicitur prime (...).

6 See below, notes 4 and 9 .

7 On determination, cf. King 2021, p. 248-267.

8 Berthold of Moosburg, Expositio, 5B, p. 116, l.134-135.

9 The adverb prime signifies that those determinations are not their essence, but rather that these determinations can be attributed to the henads only in that they are their causes. Also, when we simply mean prime unum, we say that it causes unity. Berthold of Moosburg, Expositio, 16oK, p. 8, l. 168-181: De primo sciendum, quod (...) prime adverbium, quod secundum grammaticos est vi verbi adiectivum, modificat terminum, cui addicitur ad standum pro simplicissimo, absolutissimo et sic illimitatissimo intentionis seu proprietatis per terminum denotatae, verbi gratia prime intellectus stat pro simplicissimo, absolutissimo et illimitatissimo intellectu, 
multiplicity, are what the prime unum is in regard to the unitates and everything else. They mediate between absolute unity and the multiplicity of the determined things.

I will analyze the way Berthold defines the number and the character of the unitates, and the specific order he assigns them.

\section{Proclus, Eriugena, and the List and Order of Henads}

One fundamental source used by Berthold to redefine in Christians terms the metaphysical status of the gods or henads is the thought of John Scotus Eriugena which he receives mainly through the Clavis physicae written by Honorius Augustodunensis during the first half of the twelfth century. ${ }^{10}$ As I have demonstrated elsewhere, ${ }^{11}$ Berthold considers the Eriugenian notion of causa primordialis to be a philosophical Christian equivalent of Proclus' henad. Thus, throughout the Expositio, Proclus' gods are identified with the Eriugenian causae primordiales which, according to the Clavis physicae (and the Periphyseon), are made by the Father in the Son (quas Pater in Filio fecit). ${ }^{12}$

The Eriugenian sources, as well as the thought of pseudo-Dionysius, play a crucial role in the Expositio when it comes to state how many and which are the causae primordiales or unitates. The list of unitates could not come from Proclus because the Elements of Theology, like the Tria opuscula, does not specify the names of the henads-although it does state that their number is finite. ${ }^{13}$ However, pseudo-Dionysius and Berthold's Eriugenian sources can clarify the origin of Berthold's own doctrine only partially. Regarding Eriugena's thought there

qui non est aliud quam quod dicitur, cum sit monarcha totius intellectualis seyrae, et per consequens est unus solus (...) et extra omnem effectum (...). Est autem duplex prime, vel simpliciter vel in determinata entium manerie. Primum est unum tantum, scilicet prime unum, quod solum et simpliciter est monarcha non unius maneriei entium, sed simpliciter totius universi (...). Prime autem secundo modo acceptum adhuc est duplex, quia vel simpliciter principaliforme respectu alicuius determinatae maneriei entium totalitervel respectu alicuius generis vel speciei entium intra determinatam maneriem conclusorum. Expositio 136B, p. 5, 73-74: (...) quod est per se, est limitatum et contractum in ipsa intentione, prime autem est illimitatum et incontractum et sic dignius limitato et contracto. Cf. Flasch 1984, p. XVII.

10 Cf. Ludueña 2013, p. 111-118; Führer, Gersh 2014, p. 307; King 2019, p. 395-414.

11 Cf. Ludueña 2013, p. 119-143.

12 Cf., e.g., Berthold of Moosburg, Expositio, 128A, p. 166, l. 22-26.

13 Proclus, Elementatio theologica, Prop. 149, p. 72, 1. 1-2: Omnis multitudo divinarum unitatum finita est et secundum numerum. 
is a significant difference, for, according to the Irish philosopher, the number of causae primordiales is infinite, and, because of this, one cannot definitively state the order of those causae..$^{14}$ Berthold, as we said, speaks of six henads or causae and he mentions them in a precise order:

prime infinitas (or virtus)
prime entitas
prime vita
prime intellectualitas
prime animealitas
prime naturalitas

The number six proceeds, as Berthold himself notes it, from Macrobius. ${ }^{15}$ Six is the first perfect number. However, the total number of unitates or bonitates seems to be related to a precise image of a universe determined by six metaphysical "intentions" conceived in a specific order.

As it is well known, the Eriugenian doctrine of the causae primordiales is, mainly, a re-elaboration of the Dionysian doctrine of the divine names. The list of divine names and the order in which Dionysius presents them constitute a sort of table of contents of his De divinis nominibus.

bonum, lumen, pulchrus, amor, extasis, zelus

existens

vita

sapientia, mens, ratio, veritas, fides

virtus, justitia, salvatio, liberatio

magnus, parvus, idem, alter, similis, dissimilis, statio, motus, aequalitas omnipotens, vetus dierum

14 The passage where Eriugena declares that the primordial causes are infinite in number (Periphyseon $623 \mathrm{D}-624 \mathrm{~A}$ ) does not appear in the Clavis nor in any the other Eriugenian sources known by Berthold. But the Eriugenian remark about the impossibility of finding an exact order of the causes did find a place in the Clavis. Cf. Honorius Augustodunensis, Clavis physicae, 118, p. 88, 1. 25-29: Ordo itaque primordialium causarum iuxta contemplantis animi arbitrium constituitur, in quantum earum cognitio de divinis causis disputantibus datur: licet enim pie philosophantibus ab unaquaque earum, prout vult, inchoare, et in qualibet earum terminum suae theoriae constituere.

15 Cf. Berthold of Moosburg, Expositio, prol. 11, p. 17, l. 401 - p. 19, l. 471; p. 19, l. 343-35o. See also Expositio 63 C, p. 183-184. 
$\operatorname{pax}$

sanctus sanctorum, rex regums, dominus dominorum, deus deorum

perfectus, unus

Being, Life, Wisdom, and Power are the Dionysian ancestors of four of the six mentioned by Berthold, i.e. prime entitas, prime vita, prime intellectualitas and prime infinitas (or virtus). Not only are there two extra henads whose names cannot be found in the De divinis nominibus (prime animealitas and prime naturalitas), but the order of Berthold's henads does not coincide with the order of Dionysius' names. In particular, the name "power" does not occupy the first place after "good" ("good", for Berthold, signifies the unum secundum essentiam as a whole, that is, the totality of the henads).

In Eriugena's Periphyseon, the most complete list of primordial causes is to be found at the beginning of book III. Fifteen causes are mentioned there. ${ }^{16}$ Berthold, however, did not know that list because the Clavis physicae only presents a summary of the passage which does not include the examples. ${ }^{17}$ However, in book II, there is another list which provides the names of fourteen causes, and this list does appear in the Clavis. ${ }^{18}$ These are:

16 The complete passage is found in Periphyseon 622B-623 C, p. 192, l. 231-20o, l. 333.

17 Honorius Augustodunensis, Clavis physicae 118, p. 88, 1. 4-14: Summae ac verae naturae est prima consideratio, qua intelligitur summa ac vera bonitas, quae nullius particeps per se bonitas est, cuius prima donatione et participatione est per se ipsam, cuius item participatione bona sunt, quaecumque bona sunt. Quae ideo per se ipsam bonitas dicitur, quia per se ipsam summum bonum participat, caetera autem bona non per se ipsa summum et substantiale bonum participant, sed per eam, quae est per se ipsam summi boni participatio. Similiter dicendum de reliquis primordialibus causis, quod sint principales eo, quod per se ipsas sunt participantes unius omnium causae, quae Deus est, alia autem omnia illarum participatione sunt, quod sunt. Berthold quotes this text at the beginning of his commentary of the second proposition of the Elementatio, cf. Berthold of Moosburg, Expositio, 2A, p. 82, $16-25$.

18 Honorius Augustodunensis, Clavis physicae 116, p. 86, 1. 21-31: Sunt igitur primordiales causae, quas rerum omnium principia divini sapientes appellant, per se ipsam bonitas, per se ipsam essentia, per se ipsam vita, per se ipsam sapientia, per se ipsam veritas, per se ipsum intellectus, per se ipsam ratio, per se ipsam virtus, per se ipsam iusticia, per se ipsam salus, per se ipsam magnitudo, per se ipsam omnipotentia, per se ipsam aeternitas, per se ipsam pax, et omnes virtutes et rationes quas semel et simul Pater fecit in Filio et secundum quas ordo omnium rerum a summo usque deorsum texitur, hoc est ab intellectuali creatura, que Deo proxima est, usque ad extremum rerum omnium ordinem, quo corpora continentur. Cf. John Scotus Eriugena, Periphyseon 616C, p. 5o6, 1. 6475-508, l. 6493: Sunt igitur primordiales causae, quas rerum omnium principia divini sapientes appellant, per se 


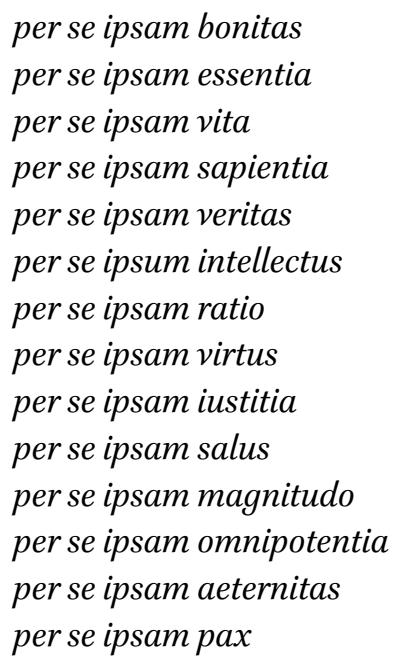

This is the most extensive list Berthold knew. ${ }^{19}$ We can compare this list with the contents of De divinis nominibus:

ipsam bonitas, per se ipsam essentia, per se ipsam vita, per se ipsam sapientia, per se ipsam veritas, per se ipsum intellectus, per se ipsam ratio, per se ipsam virtus, per se ipsam iustitia, per se ipsam salus, per se ipsam magnitudo, per se ipsam omnipotentia, per se ipsam aeternitas, per se ipsam pax, et omnes virtutes et rationes, quas semel et simul pater fecit in filio, et secundum quas ordo omnium rerum a summo usque deorsum texitur, hoc est ab intellectuali creatura, quae deo post deum proxima est, usque ad extremum rerum omnium ordinem, quo corpora continentur.

19 He also knows (directly or through Albert the Great) a scholium of the so-called Dionysian Corpus of Paris which gives a list of five causes. See Berthold of Moosburg, Expositio, prol. 4, p. 10, l. 155-174 (sec. cod. Paris. lat. 17341): 'Causae primordiales sunt, quas Graeci ideas vocant, hoc est species vel formas aeternas et incommutabiles, secundum quas et in quibus visibilis mundus formatur et regitur. Ideoque a Graecorum sapientibus potyn appellari meruerunt, hoc est principalia exempla, quae Pater in Filio fecit et per Spiritum sanctum effectus suos dividit atque multiplicat. Porismata quoque vocantur, id est praedestinationes: in his enim quaecumque divina providentia et fiunt et facta sunt simul et semel et incommutabiliter praedestinata sunt; nil enim naturaliter in creatura visibili et invisibili oritur, praeter quod in eis ante omnia tempora et loca praedefinitum et praeordinatum est.' Et post pauca: 'Ideae a philosophis divinae voluntates appellari solent et praecipue a Platonicis, quoniam quaecumque voluit Deus facere, in ipsis principaliter et causaliter fecit.' Et infra: 'Has formas sive ideas Dionysius ceterique sancti appellant per se ipsam bonitas, per se ipsam essentia, per se ipsam vita, per se ipsam virtus, per se ipsam sapientia ... Quaecumque enim bona sunt, participatione per se boni bona sunt, et quaecumque sunt, participatione per se essentiae sunt, et quaecumque vivunt, participatione per se vitae vivunt (et sic est de aliis participationibus et participantibus). (...) Nulla siquidem virtus sive generalis sive spe- 


\section{De divinis nominibus $\quad$ Clavis physicae 116}

bonum, lumen, pulchrus, amor, extasis, zelus perse ipsam bonitas

existens

per se ipsam essentia

vita

per se ipsam vita

sapientia, mens, ratio, veritas, fides

per se ipsam sapientia

per se ipsam veritas

per se ipsum intellectus

per se ipsam ratio

virtus, justitia, salvatio, liberatio

per se ipsam virtus

per se ipsam iusticia

per se ipsam salus

magnus, parvus, idem, alter, similis, dissimilis,

per se ipsam magnitude

statio, motus, aequalitas

omnipotens, vetus dierum

per se ipsam omnipotentia

per se ipsam aeternitas

$\operatorname{pax}$

per se ipsam pax

sanctus sanctorum, rex regums, dominus domi-

norum, deus deorum

perfectus, unus

There is a manifest relation between Berthold's list of henads and those lists he read in Dionysius and the Clavis physicae. But we cannot find in either the prime

cialis in natura rerum invenitur, quae a primordialibus causis ineffabili participatione non procedit'. 
animealitas and the prime natura, nor are the others mentioned in the same order as in the Expositio. A long tradition, in which the De divinis nominibus belongs, justifies the descending order: being, life, thought. But this does not explain the priority Berthold concedes to prime virtus, first among the unitates.

As for the two lowest henads, the source seems to be proposition 20 of the Elements of Theology, for according to it: "Omnibus corporibus superior est animae substantia, et omnibus animabus superior est intellectualis natura, et omnibus intellectualibus hypostasibus superius ipsum unum". Berthold's master, Dietrich of Freiberg, had based on this proposition his doctrine of the four ontological strata of the universe (maneries): the One, the intellects, the souls, and the bodies. ${ }^{20}$ Between the One and the intellectual hypostasis, Bertholds adds the level of the henads, but maintains the rest. The determination of everything that is not tantum unum is done by the henads. Berthold seems to take two levels, not mentioned by Dionysius or Eriugena, from this theorem of Proclus already used by Dietrich: the level of souls (prime animealitas) and the level of bodies (prime naturalitas). ${ }^{21}$

As to the prominent place accorded to prime virtus by Berthold, we must read his explanation of proposition 9o of the Elements of Theology. According to it, there is a prôton péras (prima finitas) and a próte apeiría (prima infinitas). The first is pure limit; the second, pure unlimited. Both are the principles that constitute everything save the One. In the Elements of Theology, these principles come immediately after the One and before the realm of henads. ${ }^{22}$ In fact, proposition 159 contends that henads derive from them: $\dot{\varepsilon} \kappa \tau \hat{\omega} \nu \pi \rho \omega t \tau v$ $\dot{\varepsilon} \sigma \tau i \nu \dot{\alpha} \times \chi \hat{\omega} \nu$ (ex primis est principiis). As Dodds-and before him, Nicholas of Methone-indicates, this is problematic. Indeed, proposition 127 states that

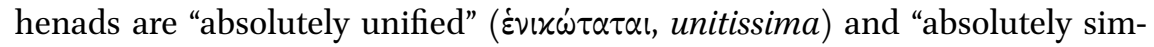
ple" ( $\dot{\alpha} \pi \lambda \circ v^{\sigma} \sigma \alpha \tau \alpha \mathrm{l}$, simplicissima). How, then, can we accept that they derive

20 Cf. Pagnoni-Sturlese 1983, p. 115-117; Libera 1994, p. 373-384; Calma 2011; Führer, Gersh 2014, p. 312-314. Dietrich of Freiberg, De intellectu et intelligibili, I, 4, 1-2, p. 138, l. 4449: Distinguit autem idem Proclus quadruplicem rerum maneriem, in quibus singulis diligens indagator, prout fuerit de proposito suo, necesse habet quaerere proprias uniuscuiusque eorum operationes. Dicit ergo propositione 20 sic: 'Omnibus corporibus superior est animae substantia et omnibus animabus superior intellectualis natura et omnibus intellectualibus hypostasibus superius ipsum unum'.

21 Nevertheless, is possible that, for Berthold, the prime animealitas signified essentially the same as the Eriugenian per se ipsam ratio.

22 Cf. Dodds 1971, p. 247; Lankila 2010, and, about Berthold's interpretation, King 2021, p. $238-248$. 
from two principles, and are, as it were, compounded by them? Are they then "infected by this radical duality"?23

Commenting on proposition 9o, Berthold denies that prima finitas and prima infinitas are intermediate principles between the One and the henads. He declares explicitly that when Proclus speaks of prima finitas he is talking about the One: "notandum, quod finitas in proposito non est aliud quam prime unum". ${ }^{24}$ To support his interpretation, he quotes a text from the last chapter of De divinis nominibus, ${ }^{25}$ and concludes: "apparet ex sententia Dionysii prime unum, quod simpliciter omnia finit et terminat, esse prime finitatem". ${ }^{26}$ By speaking of prime finitas (not of prima finitas), Berthold openly affirms that prime unum is the cause of all limit. According to Proclus, apeiría should be associated with power, ${ }^{27}$ and Berthold agreed with him, but the latter affirms that the One is pure act and, because of this, is above all power (super totam virtutem). ${ }^{28}$ Thus, infinitas derives from prime finitas or prime unum: "prime infinitas et omnis infinitas est effectus finitatis, scilicet prime unius". 29 The prime unum confers a limit upon all things, that is to say makes everything an unum. In respect to any further determination, prime infinitas or virtus occupies the first place, is the first henad and the most universal: prima infinitas (...) est (...) prima unitas intra ordinem unialem. Berthold has recourse once more to pseudo-Dionysius' De divinis nominibus, this time to chapter 8, devoted precisely to the divine name of virtus. There it is said that virtus subsists super omnia creata, that is why ad omnia vadit. ${ }^{30}$

This complex dialogue between Berthold's sources finds an expression in a passage of the Expositio when it comes the time to comment on proposition

23 Dodds 1971, p. 281: "It is somewhat surprising that the henads, which are henikótatai and haploústatai (prop. 127), should be infected by this radical duality: Pôs sýnthetoi hoi theoí; asks Nicolaus [of Methone] à propos of the present passage, and I confess I do not know the answer."

24 Berthold of Moosburg, Expositio, 9oA, p. 154, 16-17.

25 Berthold of Moosburg, Expositio, p. 154, 16-17: Unde et de prime uno, quod est prime finitas, sic dicit Dionysius libro De divinis nominibus cap. 13, cuius titulus est: 'De perfecto et uno', et de perfecto sic dicit: 'Igitur perfectum quidem est'. Et infra: 'Sed et sicut superperfectum secundum omnium excessum et omnem quidem infinitatem terminans super omnem autem terminum extentum et a nullo captum aut comprehensum, etc. Cf. Dionysius Ps.-Areopagita, De divinis nominibus, 13, 1, 977 B.

26 Berthold of Moosburg, Expositio, 9oA, p. 155, l. 38-39.

27 Cf. Dodds 1971, p. 247.

28 Berthold of Moosburg, Expositio, 9oC, p. 156, 61-62.

29 Berthold of Moosburg, Expositio, 9oC, p. 156, 68-69.

30 Berthold of Moosburg, Expositio, ${ }_{3}$ B, p. 94, 87-88. 
128 of the Elements of Theology: "Omnis deus a propinquioribus quidem participatus immediate participatur, a remotioribus autem per media vel pauciora vel plura aliqua". The first section of the suppositum is devoted to the statement that the henads or primordial causes are participated by everything that comes after them. Thus "dii (...) praecedunt omnia, quaecumque se participant et quorum essentia participatio est". Then he quotes three texts. The first one is a passage taken from the Clavis physicae about the nature of the primordial causes, "quae Pater in Filio fecit et per Spiritum sanctum in effectus suos dividit atque multiplicat". The second is a passage from De divinis nominibus, where Dionysius speaks about the "in Deo (...) rationes substantificas et singulariter praeexistentes (...) secundum quas supersubstantialis essentia omnia praedefinivit et produxit". The third is, again, a text from the Clavis - precisely the passage referred to above, where it presents the list of primordial causes from book II of the Periphyseon. Now, if one compares Berthold's quotation and the original text as read in the Clavis, one can observe that the Dominican master alters the text of the Clavis so that it conforms to his own interpretation of the Proclean doctrine of henads:

Clavis physicae 116

Sunt igitur primordiales causae, quas rerum omnium principia divini sapientes appellant, per se ipsam bonitas,

per se ipsam essentia, per se ipsam vita, per se ipsam sapientia, per se ipsam veritas, per se ipsam intellectus, per se ipsam ratio, per se ipsam virtus, per se ipsam iusticia, per se ipsam salus, per se ipsam magnitudo, per se ipsam omnipotentia, per se ipsam aeternitas, per se ipsam pax, et omnes virtutes et rationes

quas semel et simul Pater fecit in Filio et secundum quas ordo omnium rerum a summo usque deorsum texitur, hoc est ab intellectuali creatura, que Deo proxima est, usque ad extremum rerum omnium ordinem, quo corpora continentur.

\section{Expositio 128A}

'Sunt igitur primordiales causae, quas rerum omnium principia divini sapientes appellant, per se ipsam bonitas,

per se ipsam potentia sive virtus, per se ipsam essentia, per se ipsam vita, per se ipsum intellectus, per se ipsam anima, per se ipsam natura,

quas simul et semel Pater fecit in Filio et secundum quas ordo omnium rerum a summo usque deorsum texitur. 
(cont.)

Clavis physicae 116

Quaecumque enim bona sunt, parcipatione per se boni bona sunt;

et quaecumque essentialiter et substantialiter subsistunt, participatione ipsius per se ipsam essentie subsistunt; et quecumque vivunt, participatione per se ipsam vitae vitam possident; similiter quaecumque sapiunt et intelligunt et rationalia sunt, participatione per se ipsam sapientiae et intelligentiae et rationis sapiunt et intelligent et ratiocinantur; eodem modo de caeteris dicendum.

Nulla siquidem virtus sive generalis sive specialis in natura rerum invenitur que a primordialibus causis participatione non procedat: sed haec omnia in summa causa existunt, ut omnes numeri in monade et omnes linaee in centro subsistunt. $^{31}$
Expositio 128A

Quaecumque enim bona sunt, participatione per se boni bona sunt,

et quaecumque virtutem habent, participatione per se virtutis ipsam habent.
Nulla siquidem virtus sive generalis sive specialis in natura rerum invenitur, quae a primordialibus causis participatione non procedat, sed haec omnia in summa causa existunt, ut omnes numeri in monade et omnes lineae in centro subsistunt.' Ista, quae praemissa sunt, extracta sunt de libro Theodori, qui dicitur Clavis. ${ }^{32}$

Berthold recognizes that what he offers is not a formal quotation, for he presents it as an extractio. The truth is that, far from being arbitrary, the modifications he introduces are, in fact, the result of a process of reflection about his sources, pagan and Christian. He copies the text literally until it mentions the first of the primordial causes, per se ipsam bonitas, which for Berthold is the same as what he calls unum (or bonum) secundum essentiam. Then, he changes the text by reducing the number of causes and altering their order so that the list matches his own doctrine. And in order to keep this trend of thought he also changes another portion of the text. Everything good is good because it participates of per se ipsam bonitas, so that everything that subsists, subsists because

31 Honorius Augustodunensis, Clavis physicae 116, p. 86, 1. 21-41.

32 Berthold of Moosburg, Expositio, 128A, p. 167, 1. 47-57. 
it participates per se ipsam essentia, etc. Berthold merely retains the first part, deletes the rest and, instead, writes: "et quaecumque virtutem habent, participatione per se virtutis ipsam habent".

His interpretation about the order of the primordial causes, their number and their meaning generates a metaphysical conception of the universe. The henads are the origin of multiplicity. They determine the product created by the prime unum, a product which is unum tantum; because "ipsa intentio boni non potest se ipsa subsistere", and therefore "recipit diversas determinationes subordinatas diversarum intentionum magis contractarum". ${ }^{33}$ The principle behind this is, as Berthold puts it, that "unum manens unum semper natum est facere unum". ${ }^{34}$

Those intentiones are the gods: "determinatio originatur et principiatur necessario a diversis et subordinatis primordialibus causis". ${ }^{35}$ Thus, even if they are simple, ${ }^{36}$ the gods constitute a ratio componibilitatis. They vary according to the extension of their causal action, and the order in which Berthold presents them reflects that variation: non omnis deus est eiusdem totalitatis. ${ }^{37}$ In this sense, prime naturalitas, which establishes the level of bodies, "infimus est et particularissimus, contractissimus et limitatissimus inter deos"; whereas "prime virtus is summus [deus] intra ordinem (...) absolutissimus et illimitatissimus" (even if not simpliciter, sed in manerie deorum).$^{38}$ The latter causes the first determination of the product created by prime unum. Only after virtus come the other determinations: being, life, intellect, soul, body. ${ }^{39}$ This is why it is the first and most universal intentio after the intentio unius. ${ }^{40}$ With the determination

33 Berthold of Moosburg, Expositio, 136E, p. 10, 1. 208-209.

34 Berthold of Moosburg, Expositio, 136E, p. 10, l. 212.

35 Berthold of Moosburg, Expositio, 136E, p. 10, l. 210-211.

36 Berthold of Moosburg, Expositio, 91A, p. 158, 21-22: In ordine namque unitatum est totalis simplicitas, utpote quae constant seu subsistunt in una intentione, scilicet unitatis seu finitatis (...).

37 Berthold of Moosburg, Expositio, 136E, p. 10, 219-224: (...) prima intentio contracta et recedens ab universalitate et totalitate boni est infinitas, quae es radix et fundamentum entium, quae appropriate sunt entia; tertia entitatem contrahens intentio est vitalitas; quarta intellectualitas; quinta animealitas; sexta corporeitas seu natura corporeitatis, et ista est ultima et particularissima omnium intentionum. Ibid. 136B, p. 5, 65-67: Licet ergo omnis deus sit totus, ut patet per iam dicta, tamen non omnis deus est eiusdem totalitatis.

38 Berthold of Moosburg, Expositio, 136C, p. 6, 99-102: Et sic infimus est et particularissimus, contractissimus et limitatissimus inter deos; summus autem intra ordinem est absolutissimus et illimitatissimus, non tamen simpliciter, sed in manerie deorum intra ordinem locatorum.

39 Berthold of Moosburg, Expositio, 14C, p. 5, 75-82.

40 Cf. Berthold of Moosburg, Expositio, 3B, p. 94, 8o-81. 
of virtus appears the first composition: unum plus virtus. But that every other determination implies virtus does not mean that prime virtus is, in some way, the cause of all the other henads - and prime entitas the cause of prime intellectus, and this the cause of prime animealitas, etc. Otherwise, since they all share the same essence, the henads would be causes of themselves. Berthold rather says that less universal henads keep a vestigium of more universal ones. Every henad after prime virtus keeps then a vestigium of it. ${ }^{41}$

\section{Conclusion}

Berthold redefines the Proclean doctrine of henads as he found it in the Elements of Theology by identifying prima finitas with the absolute One, and prima infinitas with the first of the henads. Moreover, he specifies the metaphysical contents of the henadic realm. To do this, he uses four of his main sources: the Clavis physicae, the De divinis nominibus, Proclus (notably proposition 20 of the Elements of Theology) and the teaching of Dietrich of Freiberg.

\section{Acknowledgements}

I am grateful to Evan King for kindly helping me out with the translation of this paper and for his suggestions.

41 Cf. Berthold of Moosburg, Expositio, 92A, p. 162, 24-26: Dico autem qualitercumque, sive tantum habeant vestigium infinitatis, sicut unitates subordinatae primae infinitati, puta prime ens, prime vita et sic de aliis unitatibus, sive sint infinita primo et per se, scilicet per essentiam, quae tamen dicuntur participare infinitate, quia non habent eam in superplenitudine, in qua stat in superioribus unitatibus et praecipue in eo, quod est prime respectu sui ipsorum, scilicet infinitum, sive habeant infinitatem secundum participationem et exemplariter sicut omnia citra ordinem infinitatum, scilicet enter entia. And Ibid., 126 prob., p. 16o, 191-198: (...) in omni ordine essentiali, qui est quoddam totum, superius sicut stans sub ordine principalis et essentialis causae et per consequens existens concausa est generans quodammodo inferius, sicut cor in animali et intellectus agens in anima; sed in diis est ordo essentialis per 113; ergo inferiores et particulariores generantur ex superioribus et neque partitis illis, scilicet superioribus, cum sint unitates et antipostaton, neque alteratis, cum sint immobiles per 26, neque habitudine, quae est appositio ad esse, plurificatis, cum non misceantur inferioribus, sed superioribus, inquam, generantibus a se ipsis fecundos processus (...). 


\section{Bibliography}

\section{Primary Sources}

Albert the Great, Summa theologiae sive de mirabile scientia Dei. Libri I, Pars I. Quaestiones 1-50A, ed. D. Siedler, Münster, Aschendorff, 1978.

Albert the Great, De causis et processu universitatis a prima causa, ed. W. Fauser, Münster, Aschendorff, 1993 .

Berthold of Moosburg, Expositio super Elementationem theologicam Procli. Prologus. Propositiones 1-13, eds M.R. Pagnoni-Sturlese, L. Sturlese, Hamburg, Meiner, 1984.

Berthold of Moosburg, Expositio super Elementationem theologicam Procli. Propositiones 14-34, eds L. Sturlese, M.R. Pagnoni-Sturlese, B. Mojsisch, Hamburg, Meiner, 1986.

Berthold of Moosburg, Expositio super Elementationem theologicam Procli. Propositiones 35-65, ed. A. Sannino, Hamburg, Meiner, 2001.

Berthold of Moosburg, Expositio super Elementationem theologicam Procli. Propositiones 66-107, ed. I. Zavattero, Hamburg, Meiner, 2003.

Berthold of Moosburg, Expositio super Elementationem theologicam Procli. Prop. 108135, ed. F. Retucci, Hamburg, Meiner, 2011.

Berthold of Moosburg, Expositio super Elementationem theologicam Procli. Prop. 136159, ed. F. Retucci, Hamburg, Meiner, 2007.

Berthold of Moosburg, Expositio super Elementationem theologicam Procli. Prop. 160183, eds U.R. Jeck, I.J. Tautz, Hamburg, Meiner, 2003.

Berthold of Moosburg, Expositio super Elementationem theologicam Procli. Propositiones 184-211, ed. L. Sturlese, unter Mitarbeit von A. Punzi, Hamburg, Meiner, 2014.

Berthold of Moosburg, Expositio super Elementationem theologicam Procli, Propositiones 184-211, ed. L. Sturlese, Roma, Edizioni di storia e letteratura, 1974.

Honorius Augustodunensis, Clavis physicae, ed. P. Lucentini, Roma, Edizioni di storia e letteratura, 1974 .

Proclus, Elementatio theologica, translata a Guillelmo de Moerbecca, ed. H. Boese, Leuven, Leuven University Press, 1987.

Proclus, The Elements of Theology, a revised Text with Translation, Introduction, and Commentary by E.R. Dodds, Oxford, Clarendon Press, 1971.

Dietrich of Freiberg, De intellectu et intelligibili, in Opera omnia 1, ed. B. Mojsisch, Hamburg, F. Meiner, 1980.

\section{Secondary Sources}

Calma, D. (2011), "Maneries”, in I. Atucha; D. Calma; C. König-Pralong; I. Zavattero (eds), Mots médiévaux offerts à Ruedi Imbach, Porto, Fédération internationale des Instituts d'études médiévales, p. 433-444.

Dodds, E.R. (1971), "Commentary”, in Proclus, The Elements of Theology, Oxford, Clarendon Press, p. 187-310. 
Flasch, K. (1984), "Einleitung", in Bertholdus de Mosburch, Expositio super Elementationem theologicam Procli. Prologus. Propositiones 1-13, M.R. Pagnoni-Sturlese, L. Sturlese (eds), Hamburg, F. Meiner, p. IX-XVIII.

Führer, M., Gersh, S. (2014), "Dietrich of Freiberg and Berthold of Moosburg”, in S. Gersh (ed.), Interpreting Proclus: From Antiquity to the Renaissance, Cambridge, Cambridge University Press, p. 299-317.

Libera, A. de (1994), Introduction à la Mystique Rhénane. D’Albert le Grand à Maître Eckhart, Paris, Éditions du Seuil.

King, E. (2019), "Eriugenism in Berthold of Moosburg's Expositio super Elementationem theologicam Procli", in D. Calma (ed.), Reading Proclus and the Book of Causes, Volume 1, Leiden/Boston, Brill, p. 394-437.

King, E.A. (2016), Supersapientia a Study of the Expositio super Elementationem theologicam Procli of Berthold von Moosburg, Clare College, Cambridge, unpublished dissertation submitted for the degree of Doctor of Philosophy in Divinity Faculty, University of Cambridge.

King, E. (2021), Supersapientia: Berthold of Moosburg and the Divine Science of the Platonists, Leiden/Boston, Brill.

Lankila, T. (2010), "Henadology in the Two Theologies of Proclus", in Dionysius 23, p. 6376.

Ludueña, E. (2013), "Eriúgena en el siglo XIV: Su presencia en la Expositio de Bertoldo de Moosburg", in Scintilla 10/2, p. 99-154.

Pagnoni-Sturlese, M.R. (1983), "Filosofia della natura e filosofía dell' intelletto in Teodorico de Freiberg e Bertoldo di Moosburg", in K. Flash (ed.), Von Meister Dietrich zu Meister Eckhart, Hamburg, F. Meiner, p. 115-127. 